\title{
Transforming Greek Epic Iliad into Taiwanese Environmental Theater: Golden Bough's Troy, Troy... Taiwan
}

\author{
Ivy I-chu Chang \\ National Chiao Tung University, Hsinchu City, Taiwan
}

\begin{abstract}
With an analysis on Golden Bough Theater's Troy, Troy... Taiwan, this article will investigate how they de-contextualize Greek Epic Iliad with an eclectic collage of the tropes of Greek epic, the techniques of environmental theater and Taiwanese local opera, and the aesthetics of Taiwanese indigenous rituals and Pili Puppetry. It will discuss how the performers transform Greek epic into a Taiwanese allegory in search of Taiwanese cultural roots and identities. Furthermore, in the cultural encounter between the East and the West, multiple folds of significance will be explored through their hybridized performance genres and rituals as well as symbolic interaction in various performance venues with different historical and cultural legacies.
\end{abstract}

Keywords: Taiwan, ritual, theater, Greek

\section{The Environmental Theatre of Troy, Troy... Taiwan}

Golden Bough Theater's Troy, Troy... Taiwan, which first premiered in 1997 and was based on Homer's epic Iliad, adapted the episodes of Aeschylus' Agamemnon and Euripides' Trojan Women. It de-contextualizes Greek Epic Iliad with an eclectic collage of the tropes of Greek epic, the techniques of environmental theater and Taiwanese local opera, and the aesthetics of Taiwanese indigenous rituals and Pili Puppetry. Director Wang Rong-yu attempts to retrieve the oldest form of theater, transforming it to a shamanist ritual. Prior to the performance, Wang had one-month fasting. Furthermore, the performance begins with a shaman/actor invoking the souls of the deceased through ode and lamentation; near the end of the performance, the same shaman/actor appears to mediate the living and the dead and to connect the past Troy with contemporary Taiwan, transforming the performance into a Taiwanese allegory in search of Taiwanese cultural roots and identities.

Staging Troy in the form of environmental theater endows it with multiple historical and cultural significances. Richard Schechner proposes six axioms of environmental theater:

(1) The theatrical event is a set of related transactions.

(2) All the space is used for the performance.

(3) The theatrical event can take place either in a totally transformed space or in "found" space.

(4) Focus is flexible and variable.

(5) All the production elements speak their own language.

(6) The text need be neither the starting point nor the goal of a production. There may be no verbal text at all (Schechner, 1973, pp. ix-xli).

Ivy I-chu Chang, Professor, Department of Foreign Languages and Literatures, National Chiao Tung University. 
The productions of Troy exemplify the axioms of environmental theater. The three different versions of Troy $(1997,2005,2015)$ have been staged in different venues (the state property-Hua-shan Winery; the Historical site-Hobe Fort; and the cultural landmark-Cloud Gate Outdoor Theater) that combine "transformed space" and "found space", which involves the dialogue and negotiation with space and hence creates different symbolic meanings, depending on the historical and cultural legacy of the performance venues. As aforementioned, the performance events were rendered with flexible and variable focus, and the texts of Greek epic or plays are not the aim of Troy's production, but the vehicle and catalyst to make possible what Grotowski calls "confrontation"- be it the confrontation between the text and the performers, between the performers and the audience, between Trojan historical past and Taiwanese contemporary lives, or between us and ourselves. The incongruous pastiche of Western and Taiwanese performance genres causes different production elements to speak their own languages that cannot be contained within one single aesthetic frame, which enhances the exchange of sensory and cognitive stimuli and generates ambiguity and ambivalence in terms of cultural identities. Furthermore, the contradictions and controversies within and without the theatrical event turn the production of Troy into a set of related transactions ranging from theater to "social drama" in Victor Turner's term (Turner, 1974, pp. 38-41).

\section{A Historical Sketch of Golden Bough: In Search of Taiwanese Body}

To comprehend how the productions of Troy allegorize Golden Bough's journey in search of Taiwan's cultural roots entails a brief historical sketch of Golden Bough and its founder Wang Rong-yu. Wang used to be a computer engineer before he found his real interest in theater. His self-discovery as of a theater director and actor reveals his journey in search of Taiwanese body as well as his ambivalent relationship with his mother Hsieh Yue-hsia, a diva of Gezaixi (Taiwanese vernacular opera), a performance genre which Wang used to despise in his youth for its "out-of-date" and vulgarity. In 1989, as Taiwan's opposition movement and little theater movement culminated, Wang followed his inner calling, giving up his job with a decent income and joining Grotowski-influenced U-Theater, in which he spared no effort to learn Growtowski's training method and sourcing techniques. Once he participated in U Theater's street performance of Luodisao of Qicai Creek, he suddenly realized that their performance was reminiscent of Gezaixi, a kind of Taiwanese local opera which his mother had been engaged in throughout her life. This experience led him to rethink and re-evaluate such a grassroots performance rooted in the soil of Taiwanese culture. In 1993, after he had adequate training and performance experience, Wang and his wife You Hui-fen, another member of $U$ Theater, founded Golden Bough Theater Troupe together. At first, they utilized Grotowski's methods of body training and sourcing techniques - a kind of body training related to ancient ritual instead of being subjected to personal subjective perspective. Later, they also used Taichi Daoyin which was said to be an integration of body, mind, soul. Wang has it, "The universe is time and space; it is Taichi and Yin/yang. Yin/yang is the sphere always moving and always flowing... Taichi is the distinctive training method for Taiwanese body and Oriental body" (YEH, 2014, p. 19). Tseng Hua-hsuan, a member of Golden Bough, compares how she benefits from Grotowski's training method and Taichi Daoyin, "From Grotowski's method I learned how to observe and be observed and how to follow and be followed on stage; from Taichi I learned to be conscious of and acting on the flow of my own body". Another member, Hsu Yong-shu, shares the similar experience, "Grotowski's training method enables us to observe the environment and the stage and to enhance our strength and resilience; Taichi allows us to commend our body as well as the flow of our energy" (p. 19). In addition, they employed Eugenio Barba's 
anthropological approach to conduct a three-year field work on Taiwanese indigenous ritual such as the procession performance in pilgrimage to Mazu goddess, Taoist exorcise ritual and the Dance of the Eight Heavenly Celestial Beings, stilt-walking, and the Tumbling-Drum Dance (Cheguzhen). Both Taichi Daoyin method and body practice of Tumbling-Drum Dance emphasized by Golden Bough stress pelvic movement and placing gravity on lower body, a kind of bodily movement that has been regarded by many Taiwanese theater practitioners including Wang Mo-lin as "Taiwanese body" which has been physically and metaphorically down to the earth, rooted in the soil (YEH, 2014, p. 97). In terms of musical, Golden Bough has often adopted the genre of Taiwanese opela, a comedic offshoot of Taiwanese vernacular opera Gezaixi, to revive traditional theater to attract local audience. Wang's utilization of Taiwanese opela was inspired by his mother Hsieh Yue-hsia who used to be a devoted actress of Gezaixi.

\section{The Ritual for Troy in 1997: A Self-reflexive Meta-narrative and Taiwanese Allegory}

In the title of Ritual for Troy, it was premiered in the ruin of Hua-shan Winery in Taipei in 1997. Prior to the performance, Wang and the actors had lived in the obsolete winery for one month, cleaning the debris of the ruin in order to nourish their love in the land. By accident, on the day prior to the performance, Wang was arrested by police for "embezzling state property". Wang was finally helped out by a few legislators and city council members. As a result, the performance was staged as scheduled. However, the accident headlined newspaper, turning the performance of Troy into a social drama tackling state authority (ZHOU, 1997; JI, 1997). Consequently, this theatrical event and its media effects motivate performance artists to make an appeal to the government to transform Hua-shan Ruin of Winery into a venue for artists' performance and exhibition. In 1999, the government renamed Hua-shan Winery as Huashan Creative Park for art creation, exhibition, and performance.

Troy in Hua-shan Winery was an ambitious project. Thematically, Wang attempts to mirror Taiwan with Troy. In ancient time, Troy was a prosperous city located in the intersection between the East and West, playing a very important role in trading and military defense, and hence it became a target of attack by Argos and its allies. In comparison, Taiwan is also a financial hub and military stronghold in the contest between the United States and the People of Republic China. In 1997, the year of Troy's premiere, Taiwan's socio-political situation was very tumultuous. Taiwanese people were proud of having directly elected their national president in 1996, yet had not totally recovered from the threat of the 1996 missile attack from the People's Republic of China prior to the presidential election in. In addition, it was the year when Taiwan was foreshadowed by the upcoming Asian Financial Tsunami in 1998. In other words, similar to Troy, despite the economic prosperity for its geographical location, Taiwan has never broken away from the threat of war from its overpowering neighbor country.

With self-reflexive meta-narrative, Director Wang purposefully allegorizes Troy as a lamentation on Taiwan's vanishing cultural homeland. At the beginning of the performance, a shaman and epic narrator, who returned from the year of 2034, visited the historical ruin and then encountered a herd of wandering ghost warriors of a vanished country, re-telling the stories in search of Taiwanese cultural roots and identities. The shaman and epic narrator was first played by an aboriginal singer Chi Hsiao-chun and later by Director Wang's mother, Hsieh Yue-hsia. At first, Chi Hsiao-chun wearing gaudy contemporary gown sang aboriginal songs and introduced the epic heroes one after another while those heroes were interrogating their own fate, the meaning of life, and their choice of life. Later on, the shaman and epic narrator was played by Hsieh Yue-hsia, who 
appeared in armor like a martial sheng (male), sang in gezaixi tune and wielded military banners to lead the army in the battle field. Then s/he foretold the upcoming unprecedented battle between Achilles and Hector.

The drama of Troy was staged by a vaudeville troupe in the form of play within play, which allowed the director to mish-mesh Trojan tragedy with Taiwanese ritualistic performance: three huge puppets accompanied with rock-and-roll music were leading the soul-invoking funeral procession, wielding large banners and shattering paper money; a group of enchanting women in flashy contemporary costumes were striking erotic poses and cursing one another and then they died in mad laughter's and macabre; in front of the death-run-down wall, a team of roller bladders were combating with a team of bikers, enacting the military contest in Greek battle field. After Trojan hero Hector was killed by Greek hero Achilles who revenged on the death of his best friend, Patroclus, the Goddess of Death wearing white mask and white robe led a procession dragging a coffin around the heroes. Scenes of massacre and slaughters were rendered as Hector's wife, Andromache, was holding an infant and hymning lullaby, which was followed by the scene that infants were beheaded, hung, and dumped here and there.

Similar to many intercultural performance, the hybridization of Greek tragedy and Taiwanese ritual aroused attention and polarized responses along the axis of universalism versus particularism. Lu Chien-chung indicates, the significance of Director Wang's experiment is to de-contextualize Taiwanese indigenous rituals and Trojan epic in order to reach the catharsis of the universal fear and pity over war. However, Lu thinks that Wang could have transcended particular time and space had he made a more daring try to make his scene more abstract with more symbolic meaning; he criticizes that some concrete settings like pillars and furnace limited the scope of the play (LU, 1998, p. 59). In contrast, Yeh Tze-hua comments that Director Wang should have made more effort to dramatize Taiwanese elements, especially the meta-narrative of the epic narrator who returns from the future for a self-reflexive critique on Taiwan's current socio-political situation. Nevertheless, Yeh indicates, compared to Wang's previous ritualistic performance, Wading Chuo-shui Creek, Troy is enacted in a more coherent style and displays more artistic flare and aesthetic depth based on its adaptation from Western literary canon (YEH, 2011, pp. 174-75).

\section{Ritual for Troy in 2005: Camping Taike Culture and Pili Video Puppetry on the Historical Site}

In 2005, Golden Bough performed Troy again in Hobe (Huwei) Fort in Tamshui, a historical site constructed by Liu Ming-chuan, a Taiwanese governor in Qing Dynasty, in 1813. The symbolic meaning of Hobe Fort lies in its testament to Taiwan's multiple colonization. The colonization history can be traced back as early as to the Spanish settlement in the sixteenth century. In 1642, Dutch established military fortifications here. In 1661, defeated by a Chinese general of Qing Dynasty, Cheng Cheng-kung, Dutch soldiers and East Indian Company withdrew, removed the cannon, and set Hobe Fort on fire.

Hobe Fort's embodiment of the legacy of Taiwan's multiple colonization reinforces and foils Golden Bough's resistant spirit in search of Taiwanese identity. Re-staging Troy in 2005, eight years away from its premiere, Wang thought that Taiwan's socio-political situation had not improved that much. In his opinion, although since 2000 Taiwan had been governed by the Democratic Progressive Party, a party that had long wielded aloft Taiwanese nationalism in contest with so-called "foreign regimes (including the Kuomingtang from the mainland China in 1949)", the ideological and ethnic antagonism within the country has been aggravated, and the cultural space and resources have remained very limited for cultural and theater practitioners to promote grassroots culture and performance because the politicians have long been abusing 
cultural resources for political elections at all levels. One of Wang's tactics to revive Taiwan's cultural identities is to elevate and embellish his mother tongue, Holo dialect, which used to be put down as a vulgar colloquial language. Wang and his wife You attempted to compose the poetry chanting and lyrics of the songs in a more graceful and sophisticating way. In an interview, Wang speaks of his intention

I invested my emotion in my homeland to this epic through Cassandra's line: "if the root of my homeland was eradicated, our folk will become withered leaves, nourishing the new sprout". I hope to revive my mother tongue through theater and performance, making it a living language in real life instead of treating it as a dead language to be preserved in archeological archive. (YEH, 2011, p. 182)

Compared to the version of 1997, Troy in 2005 was more magnificent and spectacular with the majestic walls and tunnels of Hobe Fort. To protect the historical site, the stage designer Chang He-chin constructed wooden platform in the main performance area, with the lighting integrating the walls and tunnels.

Stage designer Wang You-hui comments on the performance space:

The stage designer utilizes the concept of contrast to design the space: large versus small, far versus near, and high versus low to stress the sublimity of the fort. However, sometimes it is hard for the audience members sitting on the two sides within the wall to follow those performers who move on the platform of the main performance area for one moment and then to focus on the top of the wall for the next moment. The vast space occasionally makes the performance out of focus. (WANG, 2005, pp. 59-60)

In this performance, Golden Bough adds more experimental elements: All the characters were dressed in flamboyant, colorful, and exaggerated costumes designed by Lai Xuan-wu in recourse of the cosplay of Taiwanese Pili puppet stars. Wearing heavy costumes, they have to dance or walk up and down the steep steps connecting the main performance area and the wall; they sing in the tune of gezaixi accompanied with Pili electronic synthesizer music. In doing so, they attract more young audience members.

Golden Bough's campy performance is reminiscent of Taike culture which arouses theater critics' discussion. The word Taike used to be a negative and discriminative term to put down Taiwanese indigenous culture. In 1999, Taike first appeared as a subversive term in music production and mass media with an album, Taike's Revenge, by Zhuoshuixi Commune. Around 2000, Taike became trendy with the rising of Taiwanese nationalism. By 2005, Taike culture peaked with its connection to the internet communities (CHENG, 2013, pp. 57-59). Taike campy aesthetics is characteristic of distastefulness, kuso, tackiness, collage, pastiche, parody, incongruity flamboyance, gaudiness, excess, earthly, vibrancy, and different-at-your-face attitude (pp. 60-61). In the campy performance of Troy, the incongruity among the graceful and elegant Holo dialect, the flamboyant and exaggerated costumes and the loud electronic synthesizer music were regarded by some theater critics and even Director Wang himself as the innovative campy aesthetics of a newly coined term "Yu-tai-ke" meaning the combination of Taike and Yuppie culture (JI, 2005; LI, 2005).

\section{Rooting and Routing Pili Video Puppetry}

To review Golden Bough's creation and performance of Troy as a journey and re-discovery of the root and route of Taiwanese vernacular performance, Pi-li video Puppetry appropriated by them is worth mentioning. Pi-li video puppetry derived from southern Chinese hand-puppet theater, a genre originated in Fujian Province that can be traced back to Ming Dynasty in the mid-sixteenth century. In the nineteenth century, it was brought to Taiwan by settlers and was usually performed outdoors in temple festivals (WU, 2005, pp. 50-58). In 1970, Pi-li video puppetry became a genre as the third-generation puppet master Huang Chun-hsiung produced the 
first serial The Confucian Martial Artist in Yun-chou for Taiwan Television Company, featuring enlarged puppets, Taiwanese dialect, fancy set design and dazzling aural and visual effects. With its narrative adapted from Chinese classical novels or folk tales, Pili video puppetry hybridizes diverse genres: Japanese manga and anime, Hong Kong Kung Fu films, and Hollywood sci-fi; in the style of electronic synthesizer music, it also mixes Taiwanese local opera and popular songs, and songs and music from American and Japanese TV and films. Huang's Confucian Martial Artist enjoyed 97\% TV rating, excelling the rating of $70 \%$ of previous televised hand puppet theater (WANG, 1984, p. 174). Nevertheless, the televised Pili-puppet show was banned by the government in 1974 under the pretext of "hindering farmers" daily work" as the government restricted Taiwanese dialect program from 1974 to 1989, but the puppet series went on VHS video. In 1994, Huang Chun-hsiung's sons, Huang Hua-chiang and Huang Wentze, established Pili International Multimedia Company and their satellite station began broadcasting in 1995 (Silvio, 2007, p. 289). 65\% of Pili puppet fans are between the ages of 20 to 25 (291). In addition to their televised Pili puppet video, they sold peripheral merchandises and organized Pili fan club online in response to the booming of the Internet in the mid-1990s. Furthermore, Pili fans began to form clubs by themselves to support individual puppet stars with the aids of Pili Company. Besides, they have been engaged with a diversity of activities: they collect and photograph puppets, draw manga, create animated cartoons, write short stories, and organize events like cosplay in which they dress themselves like the puppet characters.

\section{Troy, Troy... Taiwan in 2015: The Wanderer's Homecoming to Cloud Gate Theater}

With the title of Troy, Troy... Taiwan in 2015, it was staged in the outdoor theater of Cloud Gate, a cultural landmark of Taiwan's performance arts. The environmental theater of Troy staged in Cloud Gate Outdoor Theater has two folds of significance: First, the performance of Troy heralds the grand opening of Cloud Gate Theater and Studio, the outcome of seven years' joint efforts of Cloud Gate, New Taipei city government and many entrepreneurs and supporters since the Cloud Gate's studio was destroyed by a blaze in 2008. The re-establishment of the Cloud Gate Theater and Studio indicates Taiwanese people's aspiration and determination to sustain their cultural landmark and treasury no matter what happen. Secondly, the Cloud Gate's invitation to Wang Rong-yu and Golden Bough reminds many audience of Wang's connection with the Cloud Gate: in Songs of Wanderers, a dance theater produced by the Cloud Gate in 1994, Wang played a monk dressed in white robe who had remained motionless on stage for ninety minutes while 3.5 tons of rice had been showering over his head and shoulder, which became not only the iconic scene of Songs of Wanderers but also a symbol of Wang's persistent pursuit of cultural roots and identities during his journey. Twenty-one years later, producing Troy, Troy... Taiwan in the newly established Cloud Gate Theater means a lot to him: like a wanderer, Wang has accomplished his goals and returned home.

In the 2015 version of Troy, Wang does away with the enactment of contemporary Taiwanese everyday life as in the previous versions but focuses on the symbolic interaction with space and refined coherent artistic form. The whole performance is rendered in a solemn tone. In what he calls "an aesthetic ritual of violence and death", the political implication is less radical and the raucous incongruity between production elements has been eliminated with more unity between the content and the form and more mature performance techniques.

Golden Bough makes best use of all available space. The square at the center of the outdoor theater is the main performance area with audience seats on two sides. On the opposite side of the square, a two-floor-high altar was constructed where Iphigenia is killed by her father Agamemnon as a sacrifice to god in exchange for 
Argo's victory. From the left of the square, the prophet Cassandra and the chorus walk slowly out of the dark woods enlightened by torches, entering the square and invoking the souls of the dead. To the farther left, the balcony of an existent building is used as Hector's home where he bids farewell to his wife Andromache and where Andromache holding her infant gazes afar, expecting Hector's homecoming. To the right of the square, another smaller platform is constructed as a forum where Achilles expresses his resentment against Agamemnon's abuse of power and his vows to fight against Hector to revenge on his good friend Patroclus' death.

To enhance the elements of Pili puppetry, Feng Cai Lun, a renown Pili electronic synthesizer music composer, is invited to be the musical superintendent. Very often, even during battle, the performers wearing heavy Pili puppet costumes place gravity on their lower bodies and move in slow motion, displaying their "Taiwanese bodies" based on their training of Taichi Daoyin and Tumbling-Drum Dance. Contrasting and incongruous elements are still used to highlight the tension and paradox between love and death and between peace and war. In a fake wedding ceremony in which Iphigenia believes that she is to be married to Achilles, red color (an auspicious color to Chinese) is utilized to add the festive and exuberant atmosphere: Iphigenia, Agamemnon are both dressed in red. Unexpectedly, Iphigenia is lifted by the escorts, moving upward to the top of the altar, where Agamemnon is waiting. No sooner than Agamemnon wields a knife to cut Iphigenia's throat, has the red sash carpet been quickly rolled from the top of the altar, covering the whole altar like blood, a symbol of violence and death. In the scene where Hectors confronts Agamemnon and then combats with Patroclus, the heroes and soldiers are ferociously wielding aloft their weapons and banners, visualizing the violence and cruelty of war, while the scene of slaughter is accompanied with sweet and soothing melody of lullaby sung by Andromache and the chorus afar, contrasting death with love and war with peace.

\section{The Significance of Golden Bough's Hybrid Aesthetics and Environmental Theater}

Producing Troy in the form of environmental theater in different times and space, Golden Bough has achieved a great variety of symbolic interaction with the transformed and found space as well as social efficacy depending on the historical and cultural legacy of the performance venues. Performing in Hua-shan Winery Ruin in 1997, they tackled the state authority by embezzling state property and hence accelerated the transformation of the official space into more democratic cultural space with the establishment of Hua-shan Creative Park for artists and performers in 1999; performing in 2005 in Hu-wei Fort, an embodiment of Taiwan's history of multiple colonization, they contested Western cultural colonization by appropriating the Western literary canon with campy Taike Culture and Pili puppetry in rooting and routing Taiwanese vernacular cultural; performing in the Cloud Gate outdoor theater in the grand opening night in 2015, they celebrated their accomplishments over decades' journey in search of Taiwanese cultural identity with more confidence and a more mature art form.

Commenting on Golden Bough's hybrid aesthetics, Liang Peiling indicates that "cultural hybridity, while an imprint and manifestation of colonial suppression, is theatrically transformed into a site of hope and deliverance" (LIANG, 2010, p. 24). Moreover, embodying folk forms and grassroots culture allows the performers to recuperate the vernacular culture that has survived the colonial censorship and stigmatization. Golden Bough's performativity of the "earthly" and heterogeneous environmental theater which combines the western canon, Taiwanese vernacular opera and Pili puppetry allows the performers and the audience to witness and to rejuvenate the docile body and its double contained by the rules and regulations of the colonial power. 
Taiwan's hybridized cultural flow and Taiwanese dynamic bodies in the cultural contact zone are hence no longer "an epistemological object" as termed by Homi Bhabha, but "an enactive, enunciatory site that opens up possibilities for other times of cultural meaning (retroactive, prefigurative) and other narrative spaces (fantasmic, metaphorical)" (Bhabha, 1997, p. 178).

Similar to any intercultural theater adapting Western canon, Troy inevitably aroused controversies and debates along the axis of universalism versus particularism or the West versus the East. Nevertheless, in the process of adapting and appropriating the Western canon, the performance artists have been faced with the unpredictability and challenge of the cross-cultural encounter, and hence become more aware of their own culture and different performance conventions as well. They have to negotiate their positions along the continuum between different source cultures, and the interstices of various cultures would open up more possibilities for them to develop their creative potential. To note Richard Schechner, misunderstanding, broken language, miscommunication, and failed transaction would inevitably occur in intercultural theater, but they should be considered "not as obstacles to be overcome but as fertile rifts or eruptions full of creative potential". (Schechner, 2002, p. 40). Investigating intercultural performance, we may go beyond the issues of authenticity or the reliability of the mimetic representation. We may generate dialogue with the "cultural others" or treat them as travelling companions in search of cross-fertilization (Schechener, 1996, pp. 41-50). From one-way influence to two-way flow, the introduction, interpretation, adaptation, and transformation of Western canon not only involve bricolage of techniques, negotiation between different culture and performance conventions but also the choice of culture, the internal structure and the external structure.

\section{References}

Balme, C. (1999). Decolonizing the stage: Theatrical syncretism and post-colonial drama. Oxford: Clarendon Press. Bhabha, H. (1997). The location of culture. London and New York: Routledge.

CHENG, P. Y. (2013). 「金枝演社」新探 (1993-2013): 臺灣現代劇場的另類美學 (A New Study of The Golden Bough Theatre,1993-2013: The Alternative Aesthetic of Taiwan Modern Theatre) (Unpublished MA Thesis, National Chung Cheng University).

HE, D. Z. (2013)，林懷民、李國修搭救「金枝」2度復活（Lin Hwai-min and Lee Kuo-Hsiu Came to the Rescue. Golden Bough is Revived Again). 《聯合報》(United Daily News).

JI, H. L. (1997). 法律VS. 藝術, 捉放王榮裕——民代、藝文人士聲援默契下《祭特洛伊》昨晚照演 (Laws vs. Arts. The Arrest and Release of Wang Rong-yu: Troy, Troy...Taiwan was Performed Successfully with the Supports from Lawmakers and Artists). 《民生報》(Minsheng Bao).

JI, H. L. (2005a). 祭特洛伊，虛擬古台灣王國，金枝演社挑戰古蹟劇場，今起滬尾砲台變身史詩場景 (Troy, Troy...Taiwan Simulates an Ancient Kingdom of Taiwan. Golden Bough Theatre Challenges Tamsui Historical Museum). 《民生報》 (Minsheng Bao) (p. 10).

JI, H. L. (2005b). 金枝演社下月推出祭特洛伊, 全程台語演出, 驗證雅台客特色 (Golden Bough Theatre Presents Troy, Troy...Taiwan Next Month in Taiwanese to Verify Its Elegant Taike Style). 《民生報》(Minsheng Bao).

KUO, L. C. (2006). 「金枝演社」拼貼歡樂 (A Joyful Melange: The Golden Bough Theare). 《臺灣光華》(Taiwan Panorama), $3,74-83$.

LI, Y. L. (2005). 金枝演社要當雅台客, 王榮裕: 台客無關貶低, 我們只是再結合雅㾂 (Golden Bough Theatre Wants to Be Elegant Taike. Wang Rong-yu: “We are only Recombining Yuppie Styles”). 《聯合報》(United Daily News) (p. C6).

LIANG, P. L. (2010). Rearticulating Cultural Hybridity: The Golden Bough Performance Society and The Lady Knight-Errant of Taiwan - Peh-sio-lan. Theatre Research International, 36(1). 20-32.

LV, J. Z. (1998). 〈古事新調一輓歌: 評《祭特洛伊》(The New Song for an Old Story is an Eulogy: Review of Troy, Troy...Taiwan). 《表演藝術》(PAR), 62(2), 58-9. 
Schechner, R. (1973). Environmental Theatere. New York and London: Applause Publisher.

Schechner, R. (2002). Multicultural Illusions. The Drama Review, 46(3), 40.

Silvio, T. (2007). Remediation and local globalizations: How Taiwan's "Digital Video Knights-Errant Puppetry" Writes the history of the new media in Chinese. Cultural Anthropology, 22(2), 285-313.

TIAN, G. P. (2005). 淡水砲台上的《祭特洛伊》(Troy, Troy...Taiwan on Hobe Fort). 《表演藝術》(PAR), 154(10), 88-9.

Turner, V. (1974). Dramas, field, and metaphors: Symbolic action in human society. Ithaca and London: Ithaca University Press.

WANG, G. (1984). Televised Puppetry in Taiwan: An example of the marriage between a modern medium and a folk medium. In

G. Wang, \& W. Dissanayake (Eds.), Continuity and Change in Communication Systems: An Asian Perspective. Norwood, NJ: Ablex.

WANG, M. L. (2005a). 從跨文化到異國情調 (From Cross-Cultural to Exoticism). 《民生報》(Minsheng Bao) (p. C10).

WANG, Y. H. (2005b). 豪華版的《祭特洛伊》(Delux Version of Troy, Troy...Taiwan). 《表演藝術》(PAR), 156(12), 59-60.

WU, M. D. (2005). 《臺灣布袋戲表演藝術之美》(Taiwan Budaixi Biaoyanyishu Zhi Mei). Taipei: Taiwan Xuesheng Shuju.

Yeh, K. C. (2014). 身體技術作為工夫實踐：六 O 至九 O 年代台灣現代劇場的修「身」(Technology of the Body as a Practice of Self-Cultivation: Askesis and Body in Taiwanese Modern Theatre, 1960s to 1990s) (Diss. Taipei National University of Arts).

Yeh, T. H. (2010). 《金枝演社的胡做仔美學》(The Taiwanese O-pei-la Aesthetics of Golden Bough Theatre) (Unpublished MA Thesis, Taipei National University of Arts).

Yeh, T. H. (2011). 《難忘的心愛的人: 金枝演社的胡做仔美學》(I Can't Forget The People I Love: The Taiwanese O-pei-la Aesthetics of Golden Bough Theatre). Taipei: Preaudience Press.

ZHOU, M. H. (1997). 古國之神未經許可降臨華山特區, 公賣局訴警究辦 (God of Ancient State Came to Huashan Area. Taiwan Tobacco and Wine Monopoly Bureau Complained to Police). 《聯合報》(United Daily News) (p. C18). 